\title{
Evolutionary Political Psychology
}

\author{
Michael Bang Petersen \\ Department of Political Science \& Government \\ Aarhus University \\ Email:michael@ps.au.dk
}

Chapter accepted for publication in

David Buss (Ed.), The Handbook of Evolutionary Psychology, John Wiley 
Social life - when organisms designed for propagation of their own genes come to depend on each other - inevitably leads to conflict. Different individuals have different interests and as a consequence, conflicts about their prioritization arise. Politics is the process of determining this prioritization. Human ancestors lived in groups for millions of years and politics have most likely constituted an evolutionarily recurrent phenomenon throughout the evolution of the genus Homo. Humans are not just social animals; they are political animals.

Evolutionary political psychology is the field concerned with the application of evolutionary psychology to the study of politics and the nature of the human political animal. Empirical work within evolutionary political psychology is accumulating at a fast pace. This chapter reviews this work. At the same time, evolutionary political psychology is a very recent field and the available theory outweighs the available data. The chapter therefore also provides descriptions of the research avenues ahead and outlines evolutionarily informed hypotheses that have yet to be tested.

The study of politics is traditionally considered the topic of the field of political science and evolutionary political psychology is an interdisciplinary endeavor seeking to answer the questions raised within political science with the analytical tools provided by evolutionary psychology. This also raises important challenges for evolutionary psychology. Humans evolved in small social groups and evolutionary psychologists have most often analyzed modern behavior that happens within small groups, such as mating, cooperation, and forms of social conflict. Modern politics, however, happens within mass societies where millions of anonymous individuals interact with each other to shape political outcomes. As reviewed below, evolutionary political psychology therefore entails a two-step 
approach: First, dissecting the adaptive problems of conflicts of interests and building testable predictions on the structure of the corresponding adaptations for political behavior. Second, analyzing about how these adaptations operate under the evolutionarily novel conditions of mass politics.

\section{What is politics?}

If we think of social life as a game, political behavior aims to negotiate the rules of that game: who is entitled to get what, when and how (Lasswell, 1950)? In its prototypical form, political behavior targets shared expectations about entitlement (Easton, 1981). For example, when a hunter obtains and eats meat during a solitary hunting expedition, this is a pursuit of the hunter's interests. But eating this meat is not necessarily a political action. Even if the hunter's band has a rule saying that all meat should be shared, it might not be a political action. The hunter's action could go unnoticed, leaving the rule unchallenged in the eyes of others. Politics enter the scene when another individual comes by and makes a claim on the meat (e.g., that he should have it or that it should be shared with the rest of the group). If the hunter refuses, perhaps stating that he is entitled to the animals he himself kills, his action becomes political. Rather than being an unnoticed rule violation, it aims to challenge and change others' expectations about entitlement.

Politics is produced by adaptations designed to solve the coordination problems that emerge from group living. There are multiple ways to organize life within and between groups. If expectations about the rules of social life are not shared this creates transaction costs such as costs from fighting and opportunity costs from constant negotiations. This sets up a selection pressure for the evolution of adaptations designed to coordinate expectations (referred to as a "sense of social 
regularity" by De Waal, 1996). Yet, each potential rule entails different costs and benefits to different individuals (DeScioli \& Kurzban, 2013). This entails a selection pressure for the evolution of adaptations designed to change the content of coordinated rules into alignment with the interests of the self. Politics is the output of these sets of adaptations.

While the folk concept of "politics" often restrictively refers only to the business of professional politicians, evolutionary psychology advances a concept that is applicable to groups at all levels. Ancestrally, it was played out within and between families, bands and tribes. Today, it is played out across a larger number of levels. This includes local groups such as the family, workplaces and communities. But it also includes the mass level such as municipalities, states and the global world.

\section{Principles of Evolutionary Political Psychology}

Evolutionary political psychology is concerned with analyzing behavior at all political levels. At the same time, the mass level is of particular interest due to the formal concentration of power and political science has mainly focused on this level. In this section, I review the key principles guiding an evolutionary approach to the study of politics in general and of mass politics in particular.

Principle 1. Evolved political psychology is designed to operate adaptively within and between small-scale groups: in a large number of territories, mass societies only emerged within the last 500 years (Diamond, 1998); too recently for the evolution of dedicated adaptations. Accordingly, any species-typical feature of human political psychology is designed by the selection pressures operating within evolutionarily recurrent groups of between 25 and 200 individuals (Kelly, 1995). This predicts that this psychology attends to factors that were adaptive to consider under 
ancestral, small-scale circumstances. Similarly, this psychology motivates solutions that worked under these circumstances. In other words, when modern individuals reason about mass political issues such as criminal justice, social welfare and immigration, they reason about them using psychological mechanisms designed to handle related adaptive problems such as counter-exploitation, cheater-detection and newcomers in the context of small-scale, ancestral group life.

Principle 2. Evolved political psychology provides a "default" structure to mass politics: the evolved, universal human political psychology is predicted to provide an underlying structure for political processes and institutions in modern mass societies. Institutions that "fit" or resonate with evolved psychology will be more likely to emerge. Accordingly, politics across societies is predicted to share key commonalities and to be oriented towards solving similar problems (Boyer \& Petersen, 2012). This does not mean that an evolutionary psychological approach entails that political institutions are everywhere the same. First, adaptive responses are context-dependent responses. Human psychology is designed to calibrate responses to the contingencies of the individual and situation in ways that would have been fitness enhancing over human evolutionary history. While the structure of social welfare institutions everywhere might emerge from a universal psychology designed to regulate help-giving and guard against cheaters, the generosity of these institutions will differ dramatically depending on whether people in specific countries perceive the number of cheaters as high or low (Aarøe \& Petersen, 2014). Second, it is most accurate to think of evolved psychology as a "rubber cage" (Boyer \& Petersen, 2012). The evolution of improvisational intelligence (Cosmides \& Tooby, 2002) allows human organisms to spend significant cognitive effort on down-prioritizing the immediate solutions motivated by this psychology and engineer alternatives suited to 
particular environmental contingencies. This implies that the architecture of evolved political psychology provides the researcher with a set of default expectations about how political processes and institutions are structured. Many divergences occur, providing important objects for explanation: How are the cognitive demands of this divergence mitigated and how are people incentivized to meet them? What are the cultural transmission processes that brought the processes and institutions into existence? The existence of mass society itself is an example of such institutional divergence.

Principle 3. Politics is an informational arms race and evolved political psychology reflects the co-evolution of informational strategies and counterstrategies: political behavior targets people's sense about who is entitled to what. As consequence, the psychology of other humans constituted the core environment that has selected for psychological adaptations for politics. In terms of selection pressures, politics has created an evolutionary arm's race between strategies (enacted by psychological adaptations) designed to down-regulate the sense of entitlement in other's and counter-strategies designed to avoid non-adaptive down-regulations. Many of the key parameters that determine relative entitlement in humans are exceptionally difficult to assess; e.g., "am I stronger than my competitor?", "is my group more numerous than the competing group?", "is my group members more committed and loyal than our rivals?", "do we have better leadership than our rivals?" Setting such parameters accurately cannot be done without relying intensely on information, including signals from others. Hence, offensive and defensive political strategies are informational strategies. A key goal in politics is to broadcast information that sets these parameters in one's favor; e.g., signaling that members of the in-group are highly committed to a common cause (hence deterring out-groups and galvanizing 
commitment among the in-group). The goal of counter-strategies is to evaluate this information and only integrate it into decision-making parameters when is evaluated to be accurate. In modern politics, the strategic use of information is clear in everything from military parades (signaling superior strength) to denigration of leaders of rival political parties (signalling superior leadership). For the evolutionary political psychologist, the symbols, parades and debates that surround politics are not merely "theater" or "cheap talk", as a rational choice theorist would argue. These are the very strategies through which political interests are pursued, designed to tap into human psychology and mobilize support or counter the mobilization of support.

Principle 4. In mass politics, evolved political psychology is responding to events and groups without direct experience but on the basis of mental simulations aided by information from others: information matters even more in large-scale relative to small-scale politics. Today, people pass judgments on people, events and groups they have no direct experience with. For example, when a crime occurs in a small group, people will often have lived together with the offender and his family for years. Today, people pass judgments on criminals on the basis of what they can piece together about motivations, background and so forth from divergent information from political elites, the media and their social network. Given that the mechanisms of the mind - including dedicated political adaptations - are information-processing mechanisms, how and whether evolved political psychology is aroused depends critically on the content of this information. Political issues are almost always multifaceted (Chong \& Druckman, 2007), involving multiple adaptive problems. Evolutionary political psychology endeavors to dissect not just the structure of adaptations for political judgment and behavior but also analyze the flow of information from elite debates and social networks and how this flow activates some 
adaptations and keep others from being activated. At times, the information provided will fail to activate any high arousal reasoning mechanisms. Under such circumstances, the human political animal is found to be ignorant of and uninterested in mass politics (Petersen \& Aarøe, 2012).

\section{Adaptations for Political Judgment}

To engage in political behavior, an actor needs to be able to solve two overarching adaptive problems. One problem is an evaluation problem: Political behavior requires abilities to pass judgments on resource distributions and the rules giving rise to them. Another problem is a behavioral problem: Political behavior requires power to change the rules into alignment with ones evaluation. I consider these in turn.

At the most general level, the evolutionary approach entails the prediction that an individual's political judgments track whether the rule under ancestral circumstances would involve fitness benefits or costs for the individual given his or hers individual and situational characteristics. Not because humans - or other organisms - are designed to consciously strive to maximize fitness. But because natural selection has sculpted human psychological adaptations to utilize input and produce output that were fitness-enhancing under ancestral circumstances (Tooby \& Cosmides, 1990).

Fitness interests are at the core of virtually all evolutionary theories. Accordingly, the study of political judgments involves the application of any available mid-range evolutionary theory (about kin selection, reciprocity, coalitions, life history, parent-offspring conflict etc.) to the particular problem of politics. Correspondingly, individual differences in political judgments emerge through multiple developmental pathways including genetic heritability (Hibbing et al., 2013). 
Navigating through this multitude of causes, this section reviews the general factors shaping political judgments: how a rule affects the self, how it affects others valuable to the self and how coalitional allies judge the rule.

How does the rule directly affect the self?

An evolutionary approach predicts that individuals favor policies that favor the individual. Ancestrally, favored resources would be, e.g., food, help and mating opportunities. In modern politics, a favored resource is money (which can translate into the just mentioned resources) and, hence, one source of conflict in politics is differences in economic interests. People who are at the receiving end of an economic policy should favor it. While a classical position in political science is to argue against the role of self-interest (Sears et al., 1980), economic self-interest does indeed have substantial effects on political judgments (Weeden \& Kurzban, 2014).

An evolutionary approach expands the notion of self-interest beyond the economic domain. Human psychology is expected to attribute value to all resources that would enhance fitness under ancestral circumstances and evolutionary psychological research has documented multiple sources of self-interested, political conflict. People's positions on rules that regulate reproduction have been found to track mating strategies such that individuals seeking committed relationships tend to favor rules that constrict sexuality, while individuals seeking multiple, short-term partners oppose such rules (Kurzban et al., 2010). Also, people who are highly motivated to avoid pathogens are more likely to oppose policies that would bring them into contact with individuals who could be bearer of pathogens, such as outgroups from distant countries (Faulkner et al., 2004). Finally, concerns about food have been shown to shape political judgments. In many modern democracies, hunger 
has been abolished. Short-term fluctuations in hunger nonetheless shapes how people think about democratic politics. When hungry, people are much more likely to approve of redistributive policies that involve transferring resources from the rich to the needy (Aarøe \& Petersen, 2013). This is not because hungry people want to share their resources with others but because they want to acquire the resources from others.

How does the rule affect others valuable to the self?

Mechanisms for political judgment should also process how rules affect others. Humans are a social species and depend critically on others. The resource states of specific others have had repercussions for the fitness of the self and human psychology is designed to factor this into political judgments.

An important way through which others are valuable to the self is through genetic relatedness. Kin are inherently valuable to us from a fitness perspective and mechanisms for political judgment should intuitively up-regulate support for rules that benefit kin. One interesting example of this comes from research on court rulings demonstrating that judges with female offspring are more likely to rule in favor of positions that favor females (Glynn \& Sen, 2014).

Unrelated others also have provided humans with fitness benefits over human evolutionary history. In general, we should expect that individuals are more supportive of rules that benefit individuals that expose features that ancestrally would have made them valuable to the self. One line of research has focused on political attitudes about criminal justice. In small-scale societies, fewer cooperation partners are available and, hence, killing or ostracizing potentially valuable individuals involves fitness costs. Reflecting this small-scale social calculus, people are motivated to rehabilitate criminals who they perceive as productive, independently of 
the seriousness of the crime (Petersen et al., 2012). Also, across cultures, there is much consensus about what counts as crime and how serious different crimes are, tracking their fitness consequences to a significant degree (Robinson et al., 2007).

Research has also explored how the psychology of social exchange shapes political judgments (Petersen, 2015). The key selection pressure involved in the evolution of social exchange relates to reciprocity: Adaptive exchange is reciprocal and human psychology including sophisticated mechanisms for detecting cheaters (i.e., non-reciprocators) (Cosmides \& Tooby, 1992). This psychology has been demonstrated to powerfully shape opinions about the most sophisticated modern group-wide exchange system: the welfare state. Across the world, people are motivated to support welfare for needy individuals who put in an effort to find a job and contribute to society but oppose welfare to individuals who are unmotivated to do so (those who are "lazy") (see, e.g., Petersen, 2012; for an overview, see Petersen, 2015). Essentially, people's support for the rules governing welfare institutions seems to be regulated by a psychology designed to scan partners for reciprocal exchanges of help. When the rules are seen to support such partners, people support the rules.

Research on coalitional psychology provides a final illustration of how political judgments are shaped by adaptive concerns about unrelated individuals. Coalitions are groups of individuals that engage in repeated, delayed and reciprocal exchanges of help and resources (Tooby \& Cosmides, 2010). Due to the selection pressure for directing resources into the exchange system that the self participates in, coalitional psychology evolved to generate preferences for directing resources towards people that are represented as fellow group members (Yamagishi \& Kiyonari, 2000). This shape political judgments such that people judge rules and institutions (related to, e.g., criminal justice or social welfare) more negatively when these 
primarily benefit out-group members such racially or ethnically different others (e.g., Gilens, 1996). This also helps explain cross-country variation in political institutions. Differences in ethnic and racial heterogeneity across countries are major causes of differences in the size of welfare states with more heterogeneous countries having smaller welfare states (Alesina \& Glaeser, 2004).

\section{How do others judge the rule?}

The importance of coalitional psychology for political judgments extends beyond being motivated to support rules that favor in-group members. In coalitions, the self support other members when their interests are at stake in exchange for support when the self's interests are at stake. A crucial part of coalitional behavior is therefore to adopt and advance the judgments of co-members of coalitions and to counter the judgments of members of competing coalitions. These strategies extend to mass politics. When people form opinions on new policies, people are likely to simply adopt their preferred political party's position and reject the opposing party's position, independently of policy content (e.g., Cohen, 2003).

Political judgments are accordingly informed by at least two general types of evolved mechanisms: First, adaptations designed to judge the fitness consequences for the self of the content of rules (in part, due to the effects on valuable others) and, second, adaptations designed to coordinate judgments with other coalitional members, independently of rule content. Because of the lack of perfect alignment between the interests of coalitional members, inputs from these sets of adaptations can lead to divergent conclusions and need to be traded off. For example, when parties change positions on an issue, their supporters tend to change their positions as well. Importantly, however, this only happens among supporters who do not consider the 
issue important. Those who consider the issue important tend to change their party preference rather their issue position (Carsey \& Layman, 2006).

\section{Adaptations for Political Behavior: Physical Dominance}

One adaptive problem is to form an adaptive representation about the political interests of the self and how they relate to the rules of the community. Another problem is to engage in political behavior to change shared rules and expectations into alignment with the self's political interests. This section reviews how adaptations relating to physical dominance, coalitions and persuasion have helped solve this adaptive problem of acquiring political power.

\section{Political Power as Status}

One of the most fundamental features shaping expectations about resource access across animal species is hierarchy (Sidanius \& Pratto, 2001). Many animals recognize that certain individuals have higher status and priority access to resources such as food and mates. For humans, this access also expands to determining the rules of resource access themselves.

A general framework for understanding status is provided by the asymmetric war of attrition model, designed to describe the adaptive problems associated with of relative asymmetries between contestants in conflict situations (Hammerstein \& Parker, 1982). The model predicts that organisms with higher fighting ability (i.e., larger size or greater strength) will escalate conflicts whereas organisms with lesser fighting ability will withdraw. Because fighting ability determines the likelihood of prevailing, a selection pressure is created for adaptations designed to regulate conflict behavior merely on assessments of relative fighting ability. Such adaptations are 
fitness-enhancing because they allow organisms to avoid costly fights in which resources most likely would be seized anyway. From these adaptations grows the existence of dominance hierarchies: motivations to cede resources without fighting are triggered in less dominant individuals in the face of more dominant individuals (Cummins, 1996). Given this, adaptations designed to solve the adaptive problem of acquiring dominance are key for political behavior; as are adaptations for adaptively pursuing the flipside of dominance, subordination, when dominance is not possible.

\section{Physical Dominance and Status}

Dominance is related to the physical capabilities of organisms. In humans, upperbody strength is particularly important (Puts et al., this volume; Sell et al., 2012) and males' political pursuit of their self-interests has been found to be shaped by their strength. Stronger males are more likely to advocate war as a means to solve international conflicts of interest (Sell et al., 2009), they are more likely to advocate for policies that favor their own group over other groups (Price et al., 2011) and they are more likely to support policies that are aligned with their economic self-interest: for poor males, strength increases support for redistributive policies whereby resources are transferred to the self from the rich; for rich males, strength increases opposition against such politics (Petersen et al., 2013). Consistent with the evolutionarily recurrent association between physical strength and political power, research has also shown that the desire for your own group to dominate other groups predicts a desire to gain greater muscularity (Swami et al., 2013). Those who seek to impose their interests on others are cognizant and desirous of increased fighting ability. 


\section{Adaptations for Political Behavior: Coalitional Psychology}

Status has the particular quality that it is zero-sum: if A has more, B has less. Accordingly, one essential part of status seeking is competitions aimed at enhancing ones own status and reducing the status of competitors. For humans, strength does not constitute the primary tool for status competitions (Von Rueden et al., 2008). The key tool for political power is to form and join coalitions with others. To achieve such strength through numbers, humans have evolved a sophisticated coalitional psychology (Tooby \& Cosmides, 2010).

\section{Coalitional Competition}

Modern politics is permeated by multilayered sets of nested coalitions from the global level and down: International alliances, states, political parties, factions within parties and so forth. In international politics, coalitions in the form of states are the key actors (Lopez et al., 2011). For domestic politics, coalitions in the form of political parties similarly play the major role in deciding political outcomes. Also outside professional politics, coalitions are exceptionally salient. For many, the provisioning of coalitional support in the form of voting is the primary form of political action and the most important determinant of the likelihood of voting for a particular candidate is whether the candidate is a member of the party that people identifies as "their" party (Miller, 1991). Consistent with a coalitional perspective, such party affiliations are mentally represented using the psychological mechanisms that represent other, key coalitional identities such as race (Pietraszewski et al., 2014).

Just as dominance hierarchies between individual is set by individual abilities to impose costs, hierarchies between coalitions are set by corresponding collective abilities. Coalitions therefore compete by utilizing a range of different strategies to 
signal relative coalitional formidability. Collective violence constitutes the most direct and hard-to-fake expression of such signaling and the available evidence suggests that humans have adapted to engage in violent collective action (Wrangham \& Glowacki, 2012). Coalitional dominance, however, is also acquired by another mean: informational warfare. Because status often grows from assessed but not utilized fighting ability, fights over status often occur without resorting to physical violence but by emitting relevant information that can change the landscape of affiliations in favorable ways for the self's coalition. In mass politics, such informational warfare in coalitional competition is routinely present in the context of so-called negative campaigning. In political campaigns, candidates spend large amounts of resources on broadcasting information about the competence of opposing candidates. A coalition without competent leadership is a weak coalition and such information could down-regulate the assessed status of the party in the eyes of the ingroup, the out-group and those unaffiliated.

The literature on negative campaigning also shows the complexities involved in informational warfare where counter-strategies for evaluating information play a significant role. Because people (presumably) recognize that negative campaigning is strategically motivated, negative campaigning is only partially effective. Among those who support the attacked candidate, informational attacks might even backfire and prompt supporters to rally around their candidate in anger (Ansolabehere \& Iyengar, 1995).

\section{Joining Coalitions}

Forming coalitions is a complex coordination task: like-minded individuals need to be located and joint attention and trust needs to be created. This adaptive problem has 
selected for psychological adaptations designed to motivate the individual to join coalitions independently of the existence of conflicts and prepare for the rapid activation of these coalitions when conflicts arise (Tooby \& Cosmides, 2010).

Adaptations for joining coalitions should estimate and trade-off two parameters: First, within the landscape of available coalitions, which coalition is most formidable? Coalitional competition influences the landscape of affiliations because the broadcasted information about relatively formidability serves as input to adaptations for joining coalitions.

Second, which coalitions have an agenda that is closest to the self? Lasting coalitional affiliations do not tend to be formed on the basis of shared interests on a narrow agenda - such as an interest in changing one particular rule - but on the basis of interest similarities across a broader set of agendas such that the particular coalition can be activated across a range of different projects. Coalitional psychology is accordingly predicted to contain mechanisms for identifying cues to the broader agendas of others and for evaluating whether the agendas of a coalition is likely to lead to support for rules and institutions that match the narrow interests of the self. Some evidence for the existence of abilities for evaluating the alignment between the political agendas of coalitions and the self comes from the voting literature. While many voters lack political knowledge, voters are at the same to surprisingly adept at "voting correctly", that is, voting for the party or candidate that best match their values and issue positions (Lau \& Redlawsk, 1997).

In modern politics, the key broad agenda utilized to make decisions about coalitional affiliation is political ideology. Ideology works as a coalitional sorting mechanism because it predicts a number of narrow issue positions among both individuals and parties and also predicts a number of basic personality constructs 
(Hibbing et al., 2013) and even cooperation and mating strategies (Weeden \& Kurzban, 2014). Commonalities at this level between coalitional members suggest that their interests will be aligned in a large number of concrete cases.

\section{Signaling Coalitional Membership}

A key adaptive problem in the context of coalitions is to ensure that fellow coalition members aid the self when needed. Because there is not perfect alignment of interests within a coalition, it is most accurate to think of a coalition as an exchange system where the exchanged resource is coalitional support: An individual provides support to other coalitional members when their key interests are at stake in exchange for support when his or her own key interests are at stake.

This set up a selection pressure for adaptations designed to send signals of commitment to the system of coalitional exchange and attend to such signals from others. Hard-to-fake signals of commitment provide information that the self will reciprocate coalitional support, which in turns incentivizes other members to provide coalitional support to the self. Over human evolutionary history, signals of coalitional allegiances have taken the form of clothing, tattoos, facial paint, participation in group rituals, and so forth (e.g., Legare \& Watson-Jones, this volume). Because coalition members share political judgments (due to both a shared broad agenda and direct coordination) this has opened for another type of coalitional signal: signals of judgments. In essence, people can express side-taking in coalitional status competitions merely be expressing an opinion.

This has multiple consequences. First, people should be sensitive to express political judgments when they are motivated to establish new relationships and are unsure about the coalitional affiliation of others. Although political views - consistent 
with a coalitional perspective - are widely shared between spouses, in short-term dating contexts people are highly motivated to withhold political allegiance or describe themselves as centrist (Klofstad et al., 2012). Second, it creates incentives for members of competing coalitions to take opposing positions merely for purposes of signaling differentiation; saying, "I am not one of them". People are prone to support policies - independently of their content - if they are promoted by their party and oppose policy if the opposing party promotes them (e.g., Cohen, 2003). That people from the same political party shares an ideology is not just a reflection of deeper commonalities in, e.g., cooperation and mating strategies but is also an effect of the coordination of coalitional signals. While the need to signal allegiance might seem overly sensitive, such signals would have been important under ancestral, smallscale conditions. Signals of allegiances convey information to by-standers and the enemy about the numeric strength of the coalition and under ancestral conditions a change in allegiance of one or two persons could determine outcomes (Wrangham \& Glowacki, 2012).

The resulting motivations are important for understanding modern political dynamics. They explain why it is extremely difficult for candidates from different political parties to express agreement on issues and why people readily respond to intense disagreement with declining political trust (Mutz \& Reeves, 2005), interpreting it as reflections of self-interested coalitional strategies. It also helps explain why politically engaged individuals are highly motivated to follow political news. Coalitional signals are dynamic and change when new issues emerge. To keep up with the game of coalitional signaling, one needs to constantly attend to the signals emitted from coalitional leaders. News programs are like fashion shows to the evolved mind: information about how to signal your identity. 


\section{Coalitional Leaders and Followers}

Due to the broad-agenda nature of coalitions, member interests are not completely overlapping. This has created a selection pressure for solutions that help coordinate which of these interests to collectively pursue and how. The formation of withincoalition hierarchies is one important evolved coordination device. In humans, hierarchies have evolved into complex exchange relationships between leaders and followers (Price \& Van Vugt, 2014). Human leaders enjoy benefits such as power and privileged access. In exchange, human leaders are expected to coordinate solutions to collective problems of the coalitions.

The precondition for the evolution of this leader-follower relationship is the sophisticated coalitional psychology of humans. Because humans can readily form coalitions and engage in coalitional action, no individual would ancestrally have been able to completely dominate a collective of individuals. In humans, exploitive behavior in a higher-ranking individual can be held in check by the possibility of the formation of coalitions between lower-ranking individuals. Because of this, human coalitional psychology has co-evolved with a psychology of counter-dominance (Boehm, 2000). This psychology imposes important constraints on the extent to which leaders can utilize coalitions to pursue their own narrow interests: leaders need to cater to the interests of the followers or be overthrown.

The psychology of counter-dominance structures modern politics in multiple ways. First, humans have adapted to influence leadership through side taking between competitors for leadership position. This implies that key features of democratic elections fit evolved intuitions. Voting, for example, is essentially a coalitional action and equivalent to taking sides in a competition. This might also help explain the 
public appetite for news that portrays politics as a strategic competitive race between candidates (see Iyengar, Norpoth \& Hahn, 2004).

Second, humans intuitively recognize a division of labor between leaders and followers. The evidence for acceptance of political authority is overwhelming (Tyler, 2006). This resonates with the representational aspect of representative democracy. It also provides a psychological basis for limited political participation because it sets up motivational incentives to lean on competent leaders for routine collective decisions and only become engaged when key interests are at stake (see Hibbing \& Theiss-Morse, 2002).

Third, counter-dominance psychology motivates a follower to only view political authority as legitimate to the extent leaders pursue the follower's interests: we evolved to monitor our leaders and keep them accountable. This is reflected in the dispersion of democracy through the world. Stable democracies are more likely to appear in resourceful countries with low rather than high levels of ethnic heterogeneity (Jensen \& Skaaning, 2012), suggesting that people primarily accept political authority that benefit their own ethnic coalition. People, however, also attend keenly to motivations in in-group leaders and withdraw support from self-interested decision-makers (Tyler, 2006). One reflection of these motivations is the massive public attention to political scandals. When politicians' personal choices are at odds with their political positions - reflecting a self-interested attempt to constrain the actions of the others but not the self - outrage ensues.

Because followers expect service in return for bestowing prestige on leaders (Price \& Van Vugt, 2014), a key input to the psychology for aligning the self with particular within-group leaders is their problem-solving competence. Perceptions of the competence of political candidates are one of the strongest predictors of vote 
choice in modern elections (Kinder et al., 1980). Furthermore, voters in modern elections utilize a range of physical cues that would have been recurrently available over human evolutionary history to make such competence judgments including facial and voice-related features of the candidates (Todorov et al., 2005). For example, people generally perceive low-pitched voices as indicative of physical prowess and strength (Puts, 2010; this volume) and, in political elections, this leads voters to prefer candidates with low-pitched voices (Tigue et al., 2012). Importantly, preferences for physical features are adaptively calibrated by contextual factors. People favor features that ancestrally would have increased the leaders ability to solve the problems facing the coalition. In times of war people prefer a leader with masculine, dominancerelated physical traits. In times of peace such features could potentially increase the likelihood of exploitation and, accordingly, people exhibit greater preferences for competent-looking, feminine individuals (e.g., Little et al., 2007).

\section{Adaptations for Political Behavior: Persuasion and Informational Vigilance}

Another set of adaptations for political behavior is designed to enable humans to pursue their interests by persuading others that their interests are aligned. Political science has offered ample evidence that modern-day politicians routinely use persuasion strategies to promote their policies and that information communicated by media and political elites can induce opinion-change among the public (Chong \& Druckman, 2007).

Persuasion strategies involve the communication of two information types to the receiver(s) (see, e.g., Griskevicius et al., 2009). First, information serving as input to psychological mechanisms that activate motivational goals aligned with support for the political rule the communicator wants to promote. If communicators, e.g., seek to 
increase opposition to generous social welfare, relevant information includes that welfare recipients are lazy, ungrateful and out-group members (i.e., cheaters rather than reciprocators). Second, information that reveals how the preferred rule supports the fulfillment of those motivational goals. If the communicators seek to promote a specific policy that tightens the eligibility criteria for welfare benefits, they need to provide information that this policy guards against cheaters and encourages reciprocation. As consequence, the success of political communication is constrained by the evolved, human psychological architecture. The fit between the communication and the input conditions of relevant psychological mechanisms determines whether a piece of information activates appropriate motivational goals. The fit between the communication and the outputs of these mechanisms determines whether the motivations translate into support for the rule that the communicator wants to promote (Arceneaux, 2012).

\section{Persuasion Strategies}

There are a number of persuasion strategies such as logically deducing a specific rule from other rules that are supported or exposing expertise in the specific domain of the rule. Here, two particular strategies - framing and moralization - are reviewed; both designed to activate relevant motivations in a receiver.

Most political decisions are complex: it is difficult to keep all relevant features accessible in working memory and most decisions involve trade-offs. In such cases, framing is a frequently used strategy (Chong \& Druckman, 2007). Framing seeks to flood the working memory of the receiver with those features that would generate support for the promoted rule by emphasizing certain features at the expense of other features of a decision situation. For example, by emphasizing information suggesting 
that many social welfare recipients are cheaters and downplaying information to the contrary, communicators can exploit cheater-detection mechanisms to increase support for policies that impose costs on welfare recipients (for an empirical demonstration, see Slothuus, 2007). Similarly, when mobilizing for war, communicators often emphasize past grievances and downplay cooperative relations with the opposing group in order to portrait the relationship as one of zero-sum competition (see Lopez et al., 2011). In the lead up to the Balkan war between Serbia and (Muslim-dominated) Kosovo, Serbian leaders continuously referred to lessons from the lost Battle at Blackbird Field between the Serbian and the Ottoman army; a battle that took place 700 hundred years early.

Another strategy is moralization. Morality is produced by adaptations designed for coordination of judgments (DeScioli \& Kurzban, 2013). In conflicts, humans have adapted to side against individuals violating the set of rules that are recognized as "moral" within the particular community. This coordinated side-taking across the entire community hinder conflicts from escalating along, for example, coalitional lines. However, due to the strong motivational force of morality (motivating observance of rules and outrage against violations; Fiske \& Tetlock, 1997), moral psychology becomes an obvious target for persuasion strategies. Because a large range of rules can, in principle, be included in the set of rules considered "moral" (as demonstrated by the vast variation in moral rules across societies), the content of this set is not static and people can seek to strategically broadcast information that promotes the inclusion of a preferred political rule into the set of moral rules (DeScioli \& Kurzban, 2013; Petersen, 2013). While a communicator might be motivated to promote a rule due to narrow self-interest, the task when moralizing is to remove this self-interest from the argumentation and 
broadcast information that makes the rule a likely coordination point for the entire collective. One commonly used tactic is to recast the rule as in the interests of everybody or, at least, of the majority. For example, the moralization of smoking in politics and beyond was significantly advanced by information of the negative effects of second-hand smoking (Rozin \& Singh, 1997). Another tactic is to recast the rule as moral by linking the specific rule to more general moral taboos ("abortion is lack of respect for life"; "the death penalty is lack of respect for life"; "homosexuality is a sin in the eyes of God" etc.) (Fiske \& Tetlock, 1997).

\section{Counter-Strategies: Informational Vigilance}

Persuasion potentially involves broadcasting false information. As consequence, the existence of persuasion strategies has created a selection pressure for the evolution of defensive mechanisms designed for counter-manipulation through informational vigilance.

Humans seem to have rapidly operating mechanisms for identifying selfinterested motivations behind moral rhetoric and for, upon the detection of such hypocrisy, triggering anger (Monin \& Merritt, 2012). One feature of these mechanisms that make them effective is that they designed to presuppose the existence of self-interested motivations (Ybarra, 2002). Consistent with the involvement of these mechanisms in modern politics, people have very clear perceptions about the different interests to which different political parties cater (Stubager \& Slothuus, 2013).

Humans also engage in motivated reasoning - they discount information (facts, arguments, etc.) that goes against the position they are currently endorsing (Kunda, 1990), something that also occurs in modern politics (Taber \& Lodge, 2006). 
By operating under the presumption that one's original position is valid, motivated reasoning increases the threshold that persuasion attempts needs to meet in order to generate a change in positions. Hence, while motivated reasoning is often portrayed as a faulty aspect of human reasoning, an evolutionary perspective suggests that one of its core adaptive functions is to set up an effective shield against manipulation (see also Mercier \& Sperber, 2011).

\section{Mass Politics is a Both Strange and Familiar Place to the Evolved Mind}

The psychological mechanisms reviewed above evolved to promote adaptive political judgments and behavior under evolutionarily recurrent circumstances. Given the recent transition from small-scale to large-scale societies, these mechanisms do not necessarily operate adaptively in the context of modern, mass politics. Mass politics is a phenomenon that is both familiar and strange to the evolved mind: familiar because mass politics is about core problems that we have adapted to solve; strange because we today need to solve them in a radically different context. In this final section, a range of implications is reviewed.

\section{The Myth of the (Ir)rational Voter}

One key difference between ancestral and modern politics is about the factors that are rational to consider. For example, in the context of ancestral interpersonal interaction, differences in upper-body strength were important. Today, in the context of mass politics, differences in upper-body strength continue to shape male political judgments but it is hardly rational to base modern views on military strength (Sell et al., 2009) or personal benefits from redistribution (Petersen et al., 2013) on one's individual strength. The continuous influence of ancestrally relevant factors in 
modern politics reflects the design of the political mind and the structure of available cues in modern politics. The human mind is an adaptation-executor (Tooby \& Cosmides, 1990), continuously scanning for cues that ancestrally would, on average, predict the presence of an adaptive problem in order to automatically bring adaptations for solving the problem online. Today, the cues that surround mass political often resembles evolutionary recurrent cues sufficiently to activate evolved political psychology that, as a consequence, comes to guide subsequent processing. Despite all the legal complexities of the modern welfare state, for example, political debates about welfare still revolves around needy individuals and requests for help, arousing our evolved help-giving psychology and the related cheater-detection mechanisms (Petersen, 2012). When new problems emerge in mass politics with no direct ancestral parallel, our evolved psychology will latch on to any available cue and interpret the novel problems as if they contained ancestral risks. For example, in modern politics, judgments on the novel issue of genetically modified products are processed by adaptations for pathogen avoidance due to the cues inherent in tinkering with food (Prokop et al., 2013), giving rise to intuitions about contamination risk.

As a consequence of the activation of adaptations designed for small-scale politics, modern political judgments will often disregard modernly rational factors and prioritize ancestrally rational factors. In this way, evolutionary political psychology parts with two major strands in political science research. One strand argues that people's political decision-making mechanisms are well-matched to mass politics because they have been "learned" from exposure to mass political debates (e.g., Lau \& Redlawsk, 1997). Another strand argues that people are "muddle-headed" and incapable of coherent political reasoning (e.g., Converse, 1964). In the perspective of evolutionary political psychology, human political psychology is ecologically 
rational. When factors such as upper-body strength or short-term hunger influence modern political attitudes it is not because humans are irrational but because our political psychology evolved to operate efficiently in the ecology of small-scale ancestral life. When the cognitive demands of small-scale and large-scale politics diverge, it will give rise to biased judgments and apparently irrational responses in the context of mass politics. This is not all bad. For example, high levels of participation in elections are often deemed normatively desirable but voting has often been viewed as irrational because the influence of a single vote is so miniscule. Seemingly, however, the desired participation is brought about by coalitional motivations to support one's party (Smirnov et al., 2010), adapted to small-scale circumstances in which the support from everyone were vital for coalitional success.

\section{The Poverty of Ecologically Valid Stimuli}

Another, important difference between ancestral and mass politics relates to the informational context. Ancestrally, adaptations for politics would (mostly) process information relating to familiar, concrete individuals in face-to-face interactions. Today, most political debates focus on individuals, groups and events that are removed from the individual and, furthermore, on abstract, social categories ("criminals", "welfare recipients", "immigrants") rather than concrete others. In mass politics, the input to political adaptations accordingly come from decoupled, mental simulations (Petersen \& Aarøe, 2014). Furthermore, these decoupled simulations are build on the basis of information provided by others (political elites, social networks, media) rather than directly experienced cues.

One consequence is that the window for persuasion strategies and informational warfare becomes larger as people are not able to routinely check 
assertions against personal experiences. A related consequence is that the potential for conflict is increased. The mental representations underlying mass political judgments are (1) less constrained by shared direct experiences and (2) rely heavily on internally generated representations. Accordingly, each psychological difference that influences the default expectations people have about the world will come to influence these representations and provide a basis for conflict. Political conflict primarily exists in the abstract debates, but less so in relation to concrete cases (e.g., Peffley et al., 1997; Petersen et al., 2011). For example, while liberals and conservatives disagree about welfare polices in general, this disagreement is dramatically decreased in debates about specific welfare recipients when evolutionarily relevant cues are available. Liberals and conservatives are equally supportive of providing welfare to reciprocators and equally likely to reject welfare to cheaters (Petersen et al., 2011). They differ primarily in their decoupled stereotypes about whether most welfare recipients are one or the other (Aarøe \& Petersen, 2014).

The absence of direct, ecologically valid information in mass politics (in addition to the legal and technical complexities of many modern issues) also means that mass political issues at times fail to activate relevant psychological mechanisms (Petersen \& Aarøe, 2012) and it is important to acknowledge the widespread nature of public ignorance of and disinterest in mass politics (Carpini \& Keeter, 1996). Hence, forming political judgments on mass political issues is only an interesting and effortless affair to the extent the underlying adaptations have been locked onto the mass political level.

Both contextual and individual factors influence whether people utilize evolved political psychology to reason about mass politics. One factor is developmental context. Exposure to politically engaged parents - and, hence, cues 
that partisanship and political judgments are important coalitional markers - has been found to increase political attention and learning (Jennings et al., 2009). Another contextual factor is current media framing. When media and political elites convey information in formats that fit evolved psychological mechanisms - through vividly described case stories rather than abstract but objectively more relevant statistical information - people become more emotionally engaged in the issue at hand (e.g., Aarøe, 2011).

One important individual difference relates to abilities for decoupled cognition. People who are more imaginative and better able to generate vivid, engaging mental pictures of absent events and groups are more likely to form extreme political judgments, to hold emotion-infused attitudes and, of particular relevance, utilize evolutionarily relevant cues in opinion-formation (e.g., cheater-detection relevant cues in the case of social welfare attitudes), suggesting that vivid, decoupled representations fuel a stronger activation of the underlying psychological adaptations (Petersen \& Aarøe, 2013). Hence, in the context of mass politics, researchers cannot understand the formation of political judgments by just considering the structure of adaptations for politics. In addition, researchers need to dissect the pathways - such as mental simulations, medias stories and political campaigns - through which ecologically valid information is (or fails to be) transmitted to those adaptations.

\section{Conclusion}

Humans are political animals; designed by natural selection to navigate the conflicts of interests pervading human evolutionary history. Politics is the process of settling these conflicts by negotiating the rules of social life. According to the present review, the related adaptive problems have selected for a political psychology designed to, 
first, judge how the rules of resource access aligns with evolutionarily recurrent fitness interest and, second, transform rules into alignment with those interests through dominance, coalition formation and persuasion.

Evolved political psychology guides conflict behavior in both the politics of everyday life (in the family, local communities and so forth) and politics at the level of modern, mass society. Human political psychology evolved to operate within ancestral small-scale groups. The context of everyday politics resemble this social ecology and, in that context, we should expect humans to be as skilled as the best-paid spin-doctor. The context of large-scale politics is, in contrast, radically different and the activation of evolved political psychology is dependent on the flow of evolutionarily recurrent cues from political elites. Without these cues, the political animal is partially a political ignorant.

\section{References}

Aarøe, L. (2011). Investigating frame strength: The case of episodic and thematic frames. Political Communication, 28(2), 207-226.

Aarøe, L., \& Petersen, M.B. (2013). Hunger Games Fluctuations in Blood Glucose Levels Influence Support for Social Welfare. Psychological science, 24(12), $2550-2556$

Aarøe, L., \& Petersen, M.B. (2013). Crowding Out Culture: Scandinavians and Americans Agree on Social Welfare in the Face of Deservingness Cues. The Journal of Politics, 76(3): 684-697.

Alesina, A., \& Glaeser, E.L. (2004). Fighting poverty in the US and Europe: A world of difference (Vol. 26). Oxford: Oxford University Press. 
Ansolabehere, S., \& Iyengar, S. (1995). Going negative: How attack ads shrink and polarize the electorate. New York: Free Press.

Arceneaux, K. (2012). Cognitive biases and the strength of political arguments. American Journal of Political Science, 56(2), 271-285.

Boehm, C. (2000). Conflict and the evolution of social control. Journal of Consciousness Studies, 7(1-2), 1-2.

Boyer, P., \& Petersen, M.B. (2012). The naturalness of (many) social institutions: evolved cognition as their foundation. Journal of Institutional economics, $8(01)$, $1-25$.

Carpini, M.D., Keeter S. 1996. What Americans Know About Politics and Why it Matters. New Haven: Yale University Press.

Carsey, T.M., \& Layman, G.C. (2006). Changing sides or changing minds? Party identification and policy preferences in the American electorate. American Journal of Political Science, 50(2), 464-477.

Chong, D., \& Druckman, J.N. (2007). Framing theory. Annual Review of Political Science, 10, 103-126.

Cohen, G.L. (2003). Party over policy: The dominating impact of group influence on political beliefs. Journal of personality and social psychology, 85(5), 808.

Converse, P.E. 1964. "The Nature of Belief Systems in Mass Publics.” In Ideology and Discontent, ed. David E. Apter. New York: The Free Press, 206-261.

Cosmides, L., \& Tooby, J. (1992). Cognitive adaptations for social exchange. The adapted mind, 163-228.

Cosmides, L., \& Tooby, J. (2002). Unraveling the enigma of human intelligence: Evolutionary psychology and the multimodular mind. The evolution of intelligence, 145-198. 
Cummins, D. D. (1996). Dominance hierarchies and the evolution of human reasoning. Minds and Machines, 6(4), 463-480.

De Waal, F.B. (1996). Good natured. Harvard University Press.

DeScioli, P., \& Kurzban, R. (2013). A solution to the mysteries of morality. Psychological bulletin, 139(2), 477.

Diamond, J.M. (1998). Guns, germs and steel: a short history of everybody for the last 13,000 years. Random House.

Easton, D. (1981). The political system: An inquiry into the state of political science. University of Chicago Press.

Fiske, A.P., \& Tetlock, P.E. (1997). Taboo trade-offs: reactions to transactions that transgress the spheres of justice. Political psychology, 18(2), 255-297.

Gilens, M. (1996). " Race Coding" and White Opposition to Welfare. American Political Science Review, 90(3), 593-604.

Glynn, A.N., \& Sen, M. (2014). Identifying Judicial Empathy: Does Having Daughters Cause Judges to Rule for Women's Issues?. American Journal of Political Science.

Griskevicius, V., Goldstein, N.J., Mortensen, C.R., Sundie, J.M., Cialdini, R.B., \& Kenrick, D.T. (2009). Fear and loving in Las Vegas: Evolution, emotion, and persuasion. Journal of Marketing Research, 46(3), 384-395.

Hammerstein, P., \& Parker, G.A. (1982). The asymmetric war of attrition. Journal of Theoretical Biology, 96(4), 647-682.

Hibbing, J.R., \& Theiss-Morse, E. (2002). Stealth democracy: Americans' beliefs about how government should work. Cambridge University Press.

Hibbing, J.R., Smith, K.B., \& Alford, J.R. (2013). Predisposed: Liberals, Conservatives, and the Biology of Political Differences. Routledge. 
Iyengar, S., Norpoth, H., \& Hahn, K.S. (2004). Consumer demand for election news: The horserace sells. Journal of Politics, 66(1), 157-175.

Jennings, M.K., Stoker, L., \& Bowers, J. (2009). Politics across generations: Family transmission reexamined. The Journal of Politics, 71(03), 782-799.

Jensen, C., \& Skaaning, S.E. (2012). Modernization, ethnic fractionalization, and democracy. Democratization, 19(6), 1117-1137.

Kelly, R. L. (1995). The foraging spectrum: Diversity in hunter-gatherer lifeways. Washington, DC: Smithsonian Institution Press.

Kinder, D.R., Peters, M.D., Abelson, R.P., \& Fiske, S.T. (1980). Presidential prototypes. Political Behavior, 2(4), 315-337.

Klofstad, C.A., McDermott, R., \& Hatemi, P. K. (2012). Do bedroom eyes wear political glasses? The role of politics in human mate attraction. Evolution and Human Behavior, 33(2), 100-108.

Kunda, Z. (1990). The case for motivated reasoning. Psychological bulletin, 108(3), 480.

Lasswell, H.D. (1950). Politics: Who gets what, when, how. New York: P. Smith.

Lau, R.R., \& Redlawsk, D.P. (1997). Voting correctly. American Political Science Review, 585-598.

Little, A.C., Burriss, R.P., Jones, B.C., \& Roberts, S.C. (2007). Facial appearance affects voting decisions. Evolution and Human Behavior, 28(1), 18-27.

Lopez, A.C., McDermott, R., \& Petersen, M.B. (2011). States in mind: Evolution, coalitional psychology, and international politics. International Security, 36(2), $48-83$.

Mercier, H., \& Sperber, D. (2011). Why do humans reason? Arguments for an argumentative theory. Behavioral and brain sciences, 34(02), 57-74. 
Miller, W.E. (1991). Party identification, realignment, and party voting: Back to the basics. The American Political Science Review, 557-568.

Monin, B., \& Merritt, A. (2012). "Moral hypocrisy, moral inconsistency, and the struggle for moral integrity." Pp. 167-184 in Mikulincer, M., \& Shaver, P., The social psychology of morality: Exploring the causes of good and evil. Washington: American Psychological Association.

Mutz, D.C., \& Reeves, B. (2005). The new videomalaise: Effects of televised incivility on political trust. American Political Science Review, 99(01), 1-15.

Peffley, M., Hurwitz, J., \& Sniderman, P.M. (1997). Racial stereotypes and whites' political views of blacks in the context of welfare and crime. American Journal of Political Science, 30-60.

Petersen, M.B. (2015). Evolutionary Political Psychology: The Origins and Structure of Heuristics and Biases in Politics. Advances in Political Psychology, forthcoming.

Petersen, M.B. (2012). Social welfare as Small-Scale help: Evolutionary psychology and the deservingness heuristic. American Journal of Political Science, 56(1), $1-16$.

Petersen, M.B. (2013). Moralization as protection against exploitation: do individuals without allies moralize more?. Evolution and Human Behavior, 34(2), 78-85.

Petersen, M.B., \& Aarøe, L. (2012). Is the political animal politically ignorant? Applying evolutionary psychology to the study of political attitudes. Evolutionary Psychology, 10(5), 802-817.

Petersen, M.B., \& Aarøe, L. (2013). Politics in the mind's eye: Imagination as a link between social and political cognition. American Political Science Review, 107(02), 275-293. 
Petersen, M.B., Sell, A., Tooby, J., \& Cosmides, L. (2012). To punish or repair? Evolutionary psychology and lay intuitions about modern criminal justice. Evolution and Human Behavior, 33(6), 682-695.

Petersen, M.B., Slothuus, R., Stubager, R., \& Togeby, L. (2011). Deservingness versus values in public opinion on welfare: The automaticity of the deservingness heuristic. European Journal of Political Research, 50(1), 24-52.

Petersen, M.B., Sznycer, D., Sell, A., Cosmides, L., \& Tooby, J. (2013). The ancestral logic of politics upper-body strength regulates men's assertion of self-interest over economic redistribution. Psychological science, 24(7), 1098-1103.

Pietraszewski, D., Curry, O.S., Petersen, M.B., Cosmides, L., \& Tooby, J. (2014). Politics and race as coalitional categories: Cross-cutting party affiliation reduces categorization by race, but not gender or age. Under review.

Price, M.E., \& Van Vugt, M. (2014). The evolution of leader-follower reciprocity: the theory of service-for-prestige. Frontiers in Human Neuroscience, 8, 363.

Price, M.E., Kang, J., Dunn, J., \& Hopkins, S. (2011). Muscularity and attractiveness as predictors of human egalitarianism. Personality and Individual Differences, $50(5), 636-640$.

Prokop, P., Ozel, M., Usak, M., \& Senay, I. (2013). Disease-threat model explains acceptance of genetically modified products. Psihologija, 46(3), 229-243.

Puts, D.A. (2010). Beauty and the beast: Mechanisms of sexual selection in humans. Evolution and Human Behavior, 31(3), 157-175.

Robinson, P. H., Kurzban, R., \& Jones, O. D. (2007). Origins of Shared Intuitions of Justice, The. Vand. L. Rev., 60, 1633.

Rozin, P., \& Singh, L. (1999). The moralization of cigarette smoking in the United States. Journal of Consumer Psychology, 8(3), 321-337. 
Sears, D.O., Lau, R.R., Tyler, T.R., \& Allen Jr, H.M. (1980). Self-interest vs. symbolic politics in policy attitudes and presidential voting. The American Political Science Review, 670-684.

Sell, A., Hone, L.S., \& Pound, N. (2012). The importance of physical strength to human males. Human Nature, 23(1), 30-44.

Sell, A., Tooby, J., \& Cosmides, L. (2009). Formidability and the logic of human anger. Proceedings of the National Academy of Sciences, 106(35), 1507315078.

Sidanius, J., \& Pratto, F. (2001). Social dominance: An intergroup theory of social hierarchy and oppression. Cambridge University Press.

Slothuus, R. (2007). Framing deservingness to win support for welfare state retrenchment. Scandinavian Political Studies, 30(3), 323-344.

Smirnov, O., Dawes, C.T., Fowler, J.H., Johnson, T., \& McElreath, R. (2010). The behavioral logic of collective action: partisans cooperate and punish more than nonpartisans. Political Psychology, 31(4), 595-616.

Stubager, R., \& Slothuus, R. (2013). What are the sources of political parties' issue ownership? Testing four explanations at the individual level. Political Behavior, $35(3), 567-588$.

Swami, V., Neofytou, R.V., Jablonska, J., Thirlwell, H., Taylor, D., \& McCreary, D. R. (2013). Social dominance orientation predicts drive for muscularity among British men. Body image, 10(4), 653-656.

Taber, C.S., \& Lodge, M. (2006). Motivated skepticism in the evaluation of political beliefs. American Journal of Political Science, 50(3), 755-769. 
Tigue, C. C., Borak, D. J., O'Connor, J. J., Schandl, C., \& Feinberg, D. R. (2012). Voice pitch influences voting behavior. Evolution and Human Behavior, 33(3), 210-216.

Todorov, A., Mandisodza, A. N., Goren, A., \& Hall, C.C. (2005). Inferences of competence from faces predict election outcomes. Science, 308(5728), 16231626.

Tooby, J., \& Cosmides, L. (1990). The past explains the present: Emotional adaptations and the structure of ancestral environments. Ethology and sociobiology, 11(4), 375-424.

Tooby, J., \& Cosmides, L. (2010). Groups in mind: The coalitional roots of war and morality. Human morality and sociality: Evolutionary and comparative perspectives, 91-234.

Tyler, T.R. (2006). Psychological perspectives on legitimacy and legitimation. Annu. Rev. Psychol., 57, 375-400.

Von Rueden, C., Gurven, M., \& Kaplan, H. (2008). The multiple dimensions of male social status in an Amazonian society. Evolution and Human Behavior, 29(6), $402-415$.

Weeden, J. \& Kurzban, R. (2014). The hidden agenda of the political mind: How we adopt self- interested positions and why we won't admit it. Forthcoming, Princeton University Press.

Kurzban, R., Dukes, A., \& Weeden, J. (2010). Sex, drugs and moral goals: reproductive strategies and views about recreational drugs. Proceedings of the Royal Society B: Biological Sciences, rspb20100608. 
Faulkner, J., Schaller, M., Park, J.H., \& Duncan, L.A. (2004). Evolved diseaseavoidance mechanisms and contemporary xenophobic attitudes. Group Processes \& Intergroup Relations, 7(4), 333-353.

Wrangham, R. W., \& Glowacki, L. (2012). Intergroup aggression in chimpanzees and war in nomadic hunter-gatherers. Human Nature, 23(1), 5-29.

Yamagishi, T., \& Kiyonari, T. (2000). The group as the container of generalized reciprocity. Social Psychology Quarterly, 116-132.

Ybarra, O. (2002). Naïve causal understanding of valenced behaviors and its implication for social information processing. Psychological Bulletin, 128, 421-441. 